\title{
Survey of land subsidence - case study: The land subsidence formation in artificial recharge ponds at South Hamadan Power Plant, northwest of Iran
}

\author{
Ahmad Khorsandi Aghai \\ Faculty of Water and Environment, Shahid Beheshti University, A.C., Tehran, Iran. \\ e-mail:a_khorsandi@sbu.ac.ir
}

The artificial recharge is a technique of aquifer conservation for land subsidence. But in this article, the phenomenon of land subsidence and the resulting cracks and fissures at the study area are formed in recharge ponds. This is a new phenomenon and in this research the geometrical properties of the fissures of recharge ponds are measured. The results reveal the existence of fine layers in the geology of the aquifer, which are displaced in the long run as the consequence of groundwater overdraft. At the site of the artificial recharge subject of this research, the difference between the quality of recharge water and the aquifer and their interaction have intensified the instability and the movement of the fine sediments. In addition, the neglect of hydraulic principles of the groundwater during the construction and operation of the recharge wells has resulted in turbulent and speed flows, intensified displacement of fine sediments and ultimately the localized subsidence at the site of the plan.

\section{Introduction}

Land subsidence and collapse are very important and problematic hydrogeological and geological phenomena, caused by various factors such as drawdown of groundwater tables resulting from overdraft of aquifers (main factor, it recovers by artificial recharge sometimes), sand accumulation in water wells, which is somehow linked to overextraction, mining activities, ground corridors, and tunnels (Qanats), deep karst phenomenon, water pipe bursting in urban areas, and in some cases ground waters and their mechanisms. Land subsidence and collapse in plains, urban areas, or anywhere else results in casualties and material damages in the following forms:

- The agricultural lands and irrigation systems are damaged.

- The surface water pumping stations and/or groundwater wells are damaged.
- The factories, power plants and access roads are damaged.

- Water of wells, Qanats are muddied and collapsed.

- Urban areas and the people's concerns are damaged.

- Land instabilities and tremors of small magnitude are induced.

In addition, the land subsidence and the resulting cracks and fissures at the study area, are formed in artificial recharge ponds that are suggested to recover groundwater table and end the land subsidence in plains. This is a new and different phenomenon with different damages and this article deals with the causes.

Some studies undertaken on land subsidence are as follows:

In Arizona USA, land subsidence in areas with fine clay particles is formed under the influence of underlying layers' consolidation (Waltman 1989). In addition in the same area, attributes the land

Keywords. Land subsidence; artificial recharge; fine sediments; quality difference of waters. 
subsidence and dense fissures to drop in groundwater tables (Pewe Troy 1990). The ground water and its actions in Florida are mentioned as effective factors in creation and expansion of sinkholes (Wilson and Beck 1992).

The land subsidence is formed by transportation of fine sand and gravel by ground water flow (White and White 1995). The land subsidence is created by the overdraft of ground water (Lewis and Schrefler 1978). Moreover, land subsidence is induced by drawdown of groundwater tables (Poland and Davis 1969). The existence of fine particles in the aquifer and their displacement and transportation are also considered as a factor for land subsidence in Hamadan Plain (Khorsandi and Abdali 2009).

An interesting and important location from the point of view of the mentioned phenomenon is Hamadan Plain in the west of Iran, where since 1991, 32 sinkholes are induced by groundwater table drawdown. For conservation of South Hamadan Power Plant wells, the artificial recharge plan was implemented, after the continued hydration the land subsidence and the resulting cracks and fissures were formed in recharge ponds and adjacent to recharge wells.

The results of this research confirm the previous conclusions and, in addition, underline the role of fine particles or fine sand, their instability in their reaction with recharge water, their displacement by ground water, the creation of small sinkholes followed by the hydraulic change in groundwater at the site of the sinkhole (increased current) and greater fine particle displacements. Furthermore, the inappropriate execution of recharge wells has led to speedy infiltration of water from surrounding gravel pack of wells and their leaching by water, all of which have contributed to subsidence at recharge ponds and the appearance of cracks and fissures in them. Therefore, based on the above, and in view of the cone depression around the recharge wells, which adds to the saturation space of the aquifer, when humidity reaches the fine sands, they become unstable and prone to potential displacement (Mathewson 1981). Therefore, the results show the fine sand in aquifer, reaction of recharge water with aquifer water, clogging of recharge wells, erosion of aquifer martial due to the speed ground water and continued pumping of water, constant, gradual or sudden land subsidence and its subsequent problems can be expected.

\section{The description of the research site and research methodology}

\subsection{The description of the research site}

The research was conducted at the Shahid Mofateh South Hamadan Power Plant in Hamadan Plain at the site of the artificial recharge of the power plant's operation wells (figure 1). At this location, there is thermoelectric plant, which uses 26 deep wells for its water requirements. The operation wells of the plants were dug to the south of the plant and parallel to the Gharechai River (figure 1). Moreover, in addition to the plant's wells, there are 11 other deep ones in villages and lands surrounding the plant. The depths of the plant wells vary from a minimum of 80 to a maximum of $176 \mathrm{~m}$, while privately operated wells around the plant are between 90 and $110 \mathrm{~m}$ deep. Due to overdraft of ground water, the depth of groundwater tables at the power plant has increased (from 1 to $5 \mathrm{~m}$ within a year from 1998 to 1999 and in a span of 4 months) and the water production level has decreased. For this reason and in the context of maintaining the discharge rate of the power plant's operation wells, the artificial recharge plan was implemented at the north and northwest of the well network and

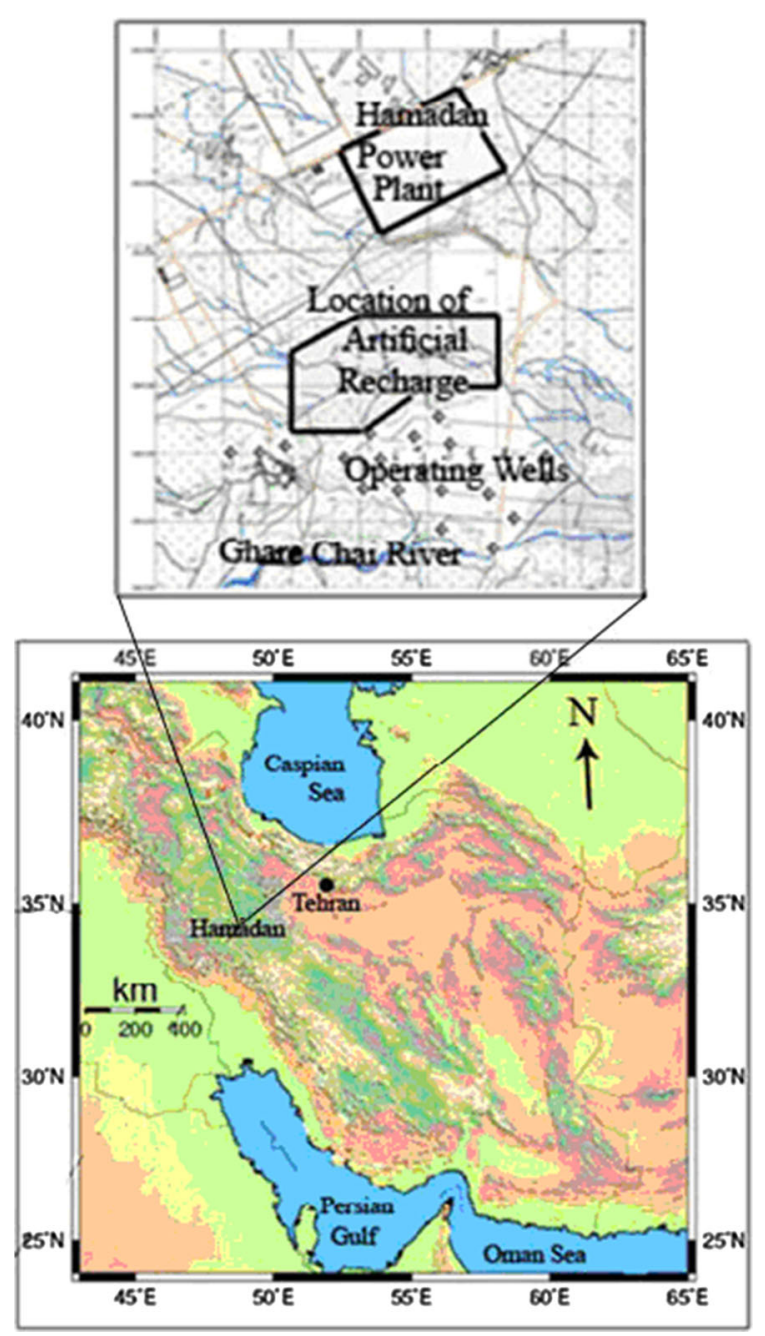

Figure 1. The location of artificial recharge plan in Hamadan. The Gharechai River is a source of artificial recharge water. The artificial recharge situation is located in north of power plant operation wells. 
along the northern bank of the Gharechai River (figure 1).

In this plan, the seasonal spring floodwater in the Gharechai River is conducted via a canal to sedimentation ponds, and then the water is led to ponds containing the recharge wells for infiltration to the aquifer. The plan consists of 20 wells, majority of which (19) have a depth of $65 \mathrm{~m}$ while the remaining one reaches down to $73 \mathrm{~m}$, all dug according to a specific array in three ponds. The wells' lining hoops have been perforated lengthwise by carbide welding process (figure 2). Theoretically, there is a ratio disparity between the surface area of the cavities and the surface of the hoop, which coupled with their shape creates a turbulent groundwater flow inside the pipe (figure 2). In addition, clogging of wells is formed by pebbles of gravel pack, resulting in groundwater flow inverted from out to the well tube and groundwater flow which is eroded by gravel pack forms hole around well (figure 2).

At the bottom of the settling and recharge ponds and following the priming, numerous cracks and fissures of different length and direction have appeared, which is the subject matter of this research. The surface geology of the research site includes Quaternary eroded deposits, most of which consist of ground water containing alluvium. Moreover, clay and fine sand have also been observed on the surface of parts located to the west, northeast, east, and southeast of the research site. The subsurface geology of the site was derived on the basis of the shape of the geological log of the three exploration wells of 120, 180 and $250 \mathrm{~m}$ depths, six piezometers at depths of 50 and $70 \mathrm{~m}$, one operation well $70 \mathrm{~m}$ deep in the east-westerly and north-southerly direction and their comparison as well as the following specifications (Khorsandi and Abdali 2009).

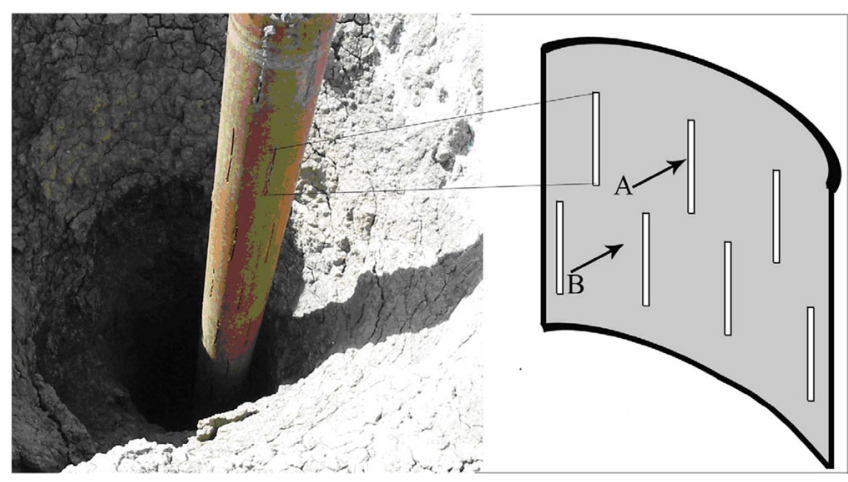

Figure 2. The recharge well and their pipe tube. A is water flow inters slot and B is water flow which encounter pipe body. The $\mathrm{B}$ water flow after encountering creates turbulent flow around contact point. The tube is clogging by gravel pack pebbles.
In the east-west direction, the aquifer bedrock in the west is located at the depth of $65 \mathrm{~m}$ in the Eocene limestone (Qom Formation), which increases to $100 \mathrm{~m}$ in the east and becomes karstic at $120 \mathrm{~m}$. In the east, the mentioned bedrock turns into the Eocene marl lime (Qom Formation) at the depth of $120 \mathrm{~m}$, which becomes pure limestone at the depth of $135 \mathrm{~m}$. Further east, the marl and clay of the upper red formation at the depth of $120 \mathrm{~m}$ form the bedrock (figure 3). Therefore, the aquifer's thickness increases by $60 \mathrm{~m}$ from west to east. Moreover, there is probably a karstic aquifer extending from west to the central part, which turns into marl lime and then marl and clay in the east. From north to south, the bedrock is in the middle section of the limestone and clay at a depth of over $90 \mathrm{~m}$. The changes in the alluvial from ground surface to the bedrock include eroded clay sediments, sand, gravel, and boulders of various sizes, which contain ground water. Among the specifications of the aquifer's filling materials is the existence of fine sand layers in the geological log of the wells, which are observed in the west and central parts, at three depths: about $10 \mathrm{~m}$ between 10 and $20 \mathrm{~m}$, and from 30 to $40 \mathrm{~m}$, while they are to be found in the east at depths of 60-70 m (figure 3).

The petrography of the aquifer's Eocene bedrock (The local geologic name is Qom Formation) is as follows:

The foundation of the limestone is the spar or micro-spar calcium carbonate crystals, which have

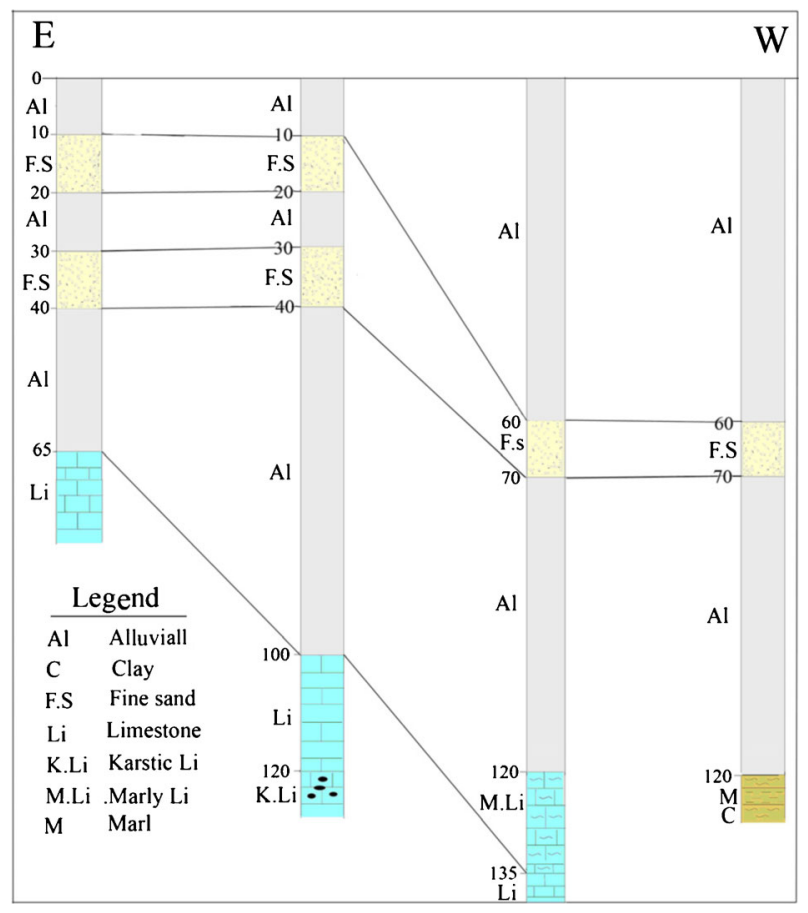

Figure 3. The correlation between geological logs of the study area and around. The different depths of bedrock of aquifer (limestone of Qom Formation) is created by fault mechanism. 
a brief cementation and recrystallization. There is about $10 \%$ of quartz in impure form. The stone's porosity is about $20-25 \%$, which shows its karstification. It should be noted that Qom Formation and its equivalent in Zagross is the limestone of Asmari Formation, which has suitable porosity and is karstic.

The lime and marl of the Qom Formation is observed in an intercalated form. The results of geotechnical tests on soil samples collected close to the Jahan Abad sinkhole located at a distance of $12 \mathrm{~km}$ east of the Shahid Mofateh power plant (beyond the scope of this research), show the relative rigidity of soil from the surface to the bedrock.

It should be noted that fine sand was observed in suspended form in the water samples during the field visit to the operation well east of the power plant. Moreover, the well operator of the plant stated that a relative amount of sand gets accumulated on the floor of the tanks collecting pumped water from the wells of the power plant, which must be discharged at appropriate intervals. Therefore the displacement of aquifer matrix is possible after the aquifer material gets eroded due to the speed of groundwater flow. Failure of confining layer may also occur while water injection. These may result in clogging and even collapse of the tube well (Satish and Tushar 2013), (figure 2).

\subsection{The research methodology}

The method of the research has been selected according to the problems created in the recharge ponds of the plan. At the bottom of the mentioned ponds and following the priming, a number of cracks and fissures appeared. After the continued hydration, the pond sites located next to the recharge wells have subsided by a minimum of 30 $\mathrm{cm}$ and a maximum of $6.5 \mathrm{~m}$ (figure 4 ).

The land subsidence is generally scattered and has led to the appearance of linear phenomena or relatively small sinkholes along the lineation (figure 5). For this reason, the study area geology is revised and geometrical properties of the cracks, fissures and sinkholes, including, direction, depth, and the width of their openings were measured. Thereafter, water samples were taken from ponds and the operation wells for chemical analysis and comparison. Moreover, the chemical analyses of water from operation wells of the power plant before and after the artificial recharge were available and used to study the recharge wells structure.

\subsubsection{The structural characteristics of the cracks and fissures}

The basic cause of subsidence and lateral movement of the land surface is increasing under the

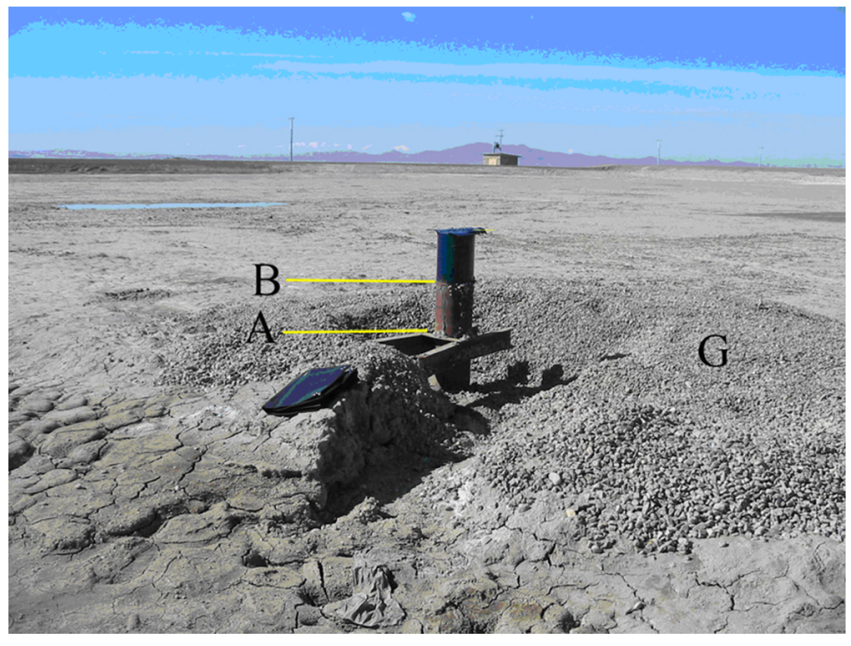

Figure 4. The land subsidence in artificial recharge ponds. $\mathrm{B}$ is old land level; $\mathrm{A}$ is new land level after subsidence and $\mathrm{G}$ is graveled around recharge well.

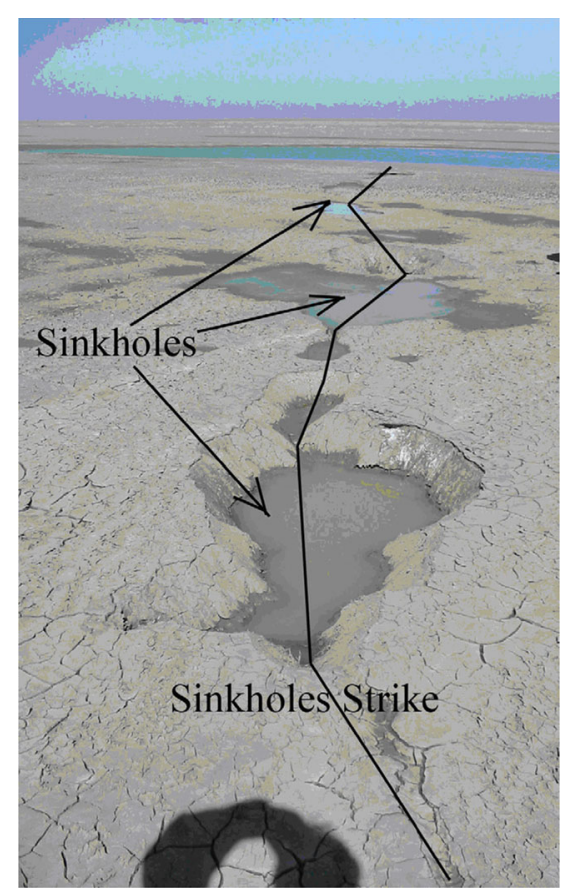

Figure 5. The small sinkholes which are formed along the lineation of ponds land subsidence by tension force in ground surface and formation of cavity and holes in depth.

intergranular pressure of the underground material (Herman Bouwer 1997). The simple equation of the above description is defined as:

$$
P_{i}=P_{t}-P_{h}
$$

where $P_{i}$ is intergranular pressure, $P_{t}$ is total pressure and $P_{h}$ is hydraulic pressure of ground water.

Changes in any of the parameters of the equation and imbalance of the aquifer, then create land subsidence and shape the cracks and fissures in the ground surface. In the present study, at 
first, groundwater overdraft changed $P_{h}$, then $P_{i}$ and land subsidence takes place. In order to control groundwater table drawdown and land subsidence, the artificial recharge plan is executed. During the ponds watering, change in hydraulic groundwater in the adjacent recharge wells and in the aquifer, groundwater quality differences with recharged water created in the ponds land

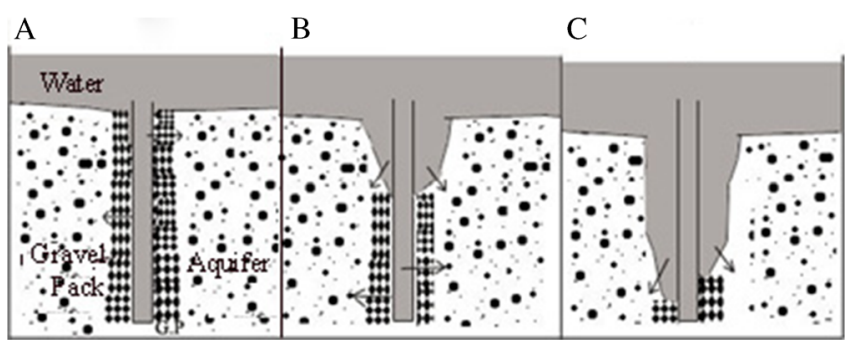

Figure 6. The schematic image of gravel packs washing by water in artificial ponds. A is recharge start, B is gravel pack washing start and $\mathrm{C}$ is complete step of gravel pack washing with greater speed flow of ground water. subsidence phenomena and resulting cracks and fissures in the Earth's surface (figure 6).

There are 46 cracks and fissures distributed in three recharge ponds. Their measured structural dimension graphs are shown in figures 7 and 8 . The widths of the openings vary between a minimum of 0.1 to a maximum of $0.7 \mathrm{~m}$ while the depths of the cracks and fissures vary from a minimum of 0.1 to a maximum of $0.35 \mathrm{~m}$.

The appearance of cracks and fissures at the floor of recharge ponds can be an indication of cavities and hollow spaces underground, which have caused a number of subsidences in the ponds.

\subsubsection{Comparison of the chemical analysis of water samples}

To identify the actions and reactions between water recharged from ponds to the ground and the aquifer's components, water samples were taken simultaneously from the ponds and 20 operation wells before and after the ponds operations for

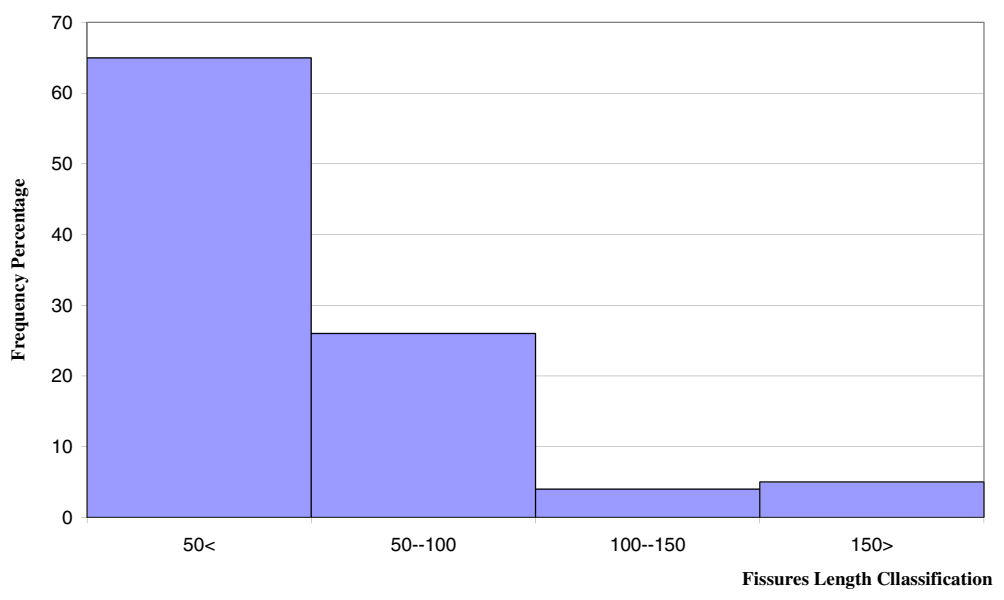

Figure 7. Diagram of the artificial recharge ponds fissure length classification.

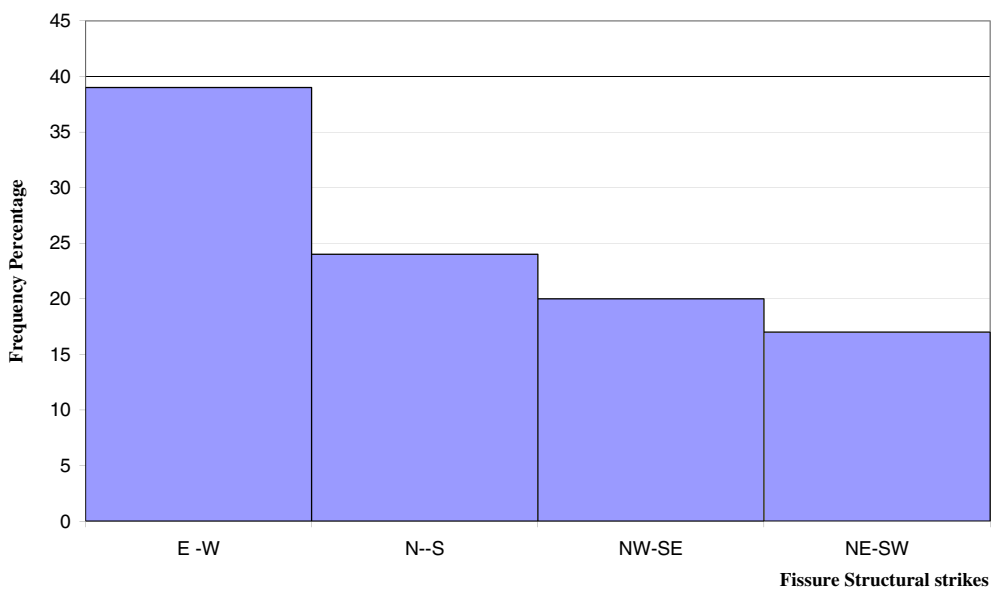

Figure 8. Diagram of the artificial recharge ponds fissure structural direct. 
chemical analysis. Then water samples were analyzed. These results are shown in figures 9 and 10.

The parameters of acidity, electrical conductivity, dry residues, and the total hardness of the water samples were selected for comparison. The average values of these parameters in 20 wells were calculated and then the computed mean averages of the samples before and after charge were compared with the ponds' inlet. These results are shown in figures 9 and 10. As can be observed, the values of electrical conductivity (EC), dry residues (T.D.S) and total hardness (T.h) of water in recharge ponds were much lower than the mentioned parameters in the well samples. For instance, the electrical conductivity of the well samples is 3 times, the residues 4 times, and the total hardness is twice their counterparts in ponds. However, a comparison between the well water samples before and after recharge shows a reduction in total hardness (figure 9, curves 2 and 3 show the difference at the final sections). The acidity of the pond water is also different from the well samples being a unit more than the latter.

The results depict a difference in the quality of recharge water and the ground water in the aquifer. In other terms, the recharge water is fresh and contains fewer salts compared to the ground water in the aquifer. This reveals a difference in

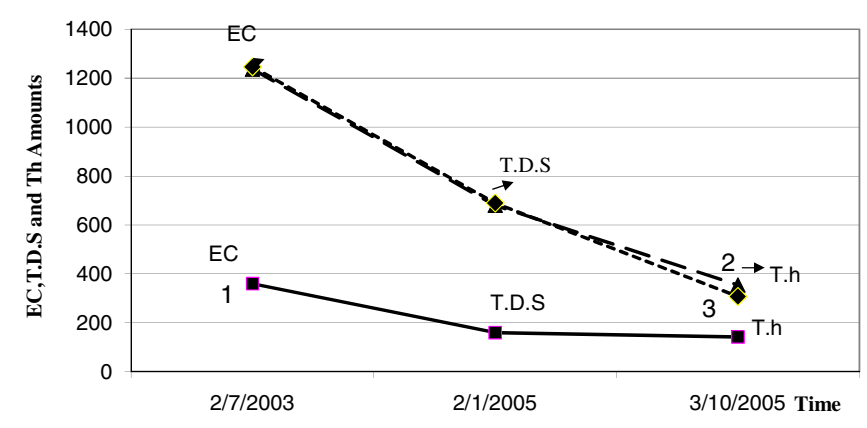

Figure 9. Diagram of comparison EC, TDS and T.h of Hamadan power plant well water samples before recharge (1), after recharge (2), and artificial recharge ponds water (3).

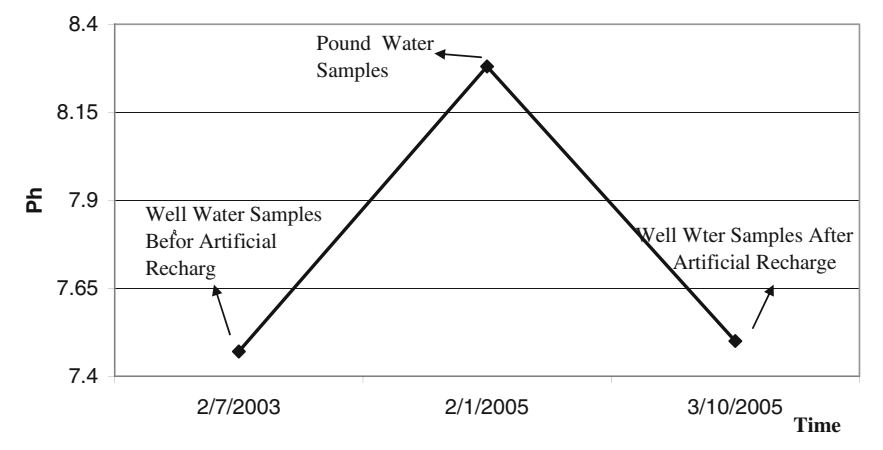

Figure 10. Diagram of the comparison acidity of the well water before, after recharge and ponds of water. the quality of aquifer water and the recharge water, creating a reaction between recharge water and the resistant fine grain sediments in the environment containing higher salt concentration (Houseman 1982). Geochemical compatibility between the recharge water and the aquifer ground water must also be considered (Herman Bouwer 2002). The most important impact concerns the swelling of the fine sediments and the reduction of Van Der Waals force down to instability level. However, important reaction considered concerns the exchange of calcium in recharge water with the sodium in the aquifer, which creates the greatest instability. In chemical analysis results, the calcium concentration in the recharge water was $150 \mathrm{mg} / \mathrm{l}$ while the sodium concentration was negligible, as opposed to the aquifer water where calcium concentration was negligible while the sodium concentration was $120 \mathrm{mg} / \mathrm{l}$, proving the above statement. Moreover, the fine sediments of the aquifer before and after the recharge operation were semi-dry or semi-saturated. The stability of the fine sediments in this state is subject to the surface tension of water at the contact point with the particles, whose pores are filled with water following the priming and saturation after recharge operations, thereby minimizing the mentioned surface tension. Thereafter, the soil becomes unstable and can be displaced with the least force. In the other situation, the fine sediments are considered to be fully saturated with aquifer water, and therefore, their stability is directly linked to the chemical composition of aquifer water and its changes. Consequently, the infiltration of recharge water of different quality to the aquifer and the cationic and ionic exchanges with the ground water, as well as changes in the chemical make up of the aquifer water are to be expected (the exchange of sodium in the aquifer water with the calcium in the recharge water). They also undermine the stability of fine sediments. The effectiveness of recharge through injection well is limited by the physical characteristics of the aquifer (Satish and Tushar 2013). The mentioned situations can occur in the plan's recharge ponds in the following three stages at the distance covering the pond's floor to the saturation level of the aquifer. The first is before the recharge operation when the groundwater table is very low (around 40-50 $\mathrm{m}$ from surface) and the fine sand is dry. The second stage is after the recharge operation until the establishment of compensation cone, and the third stage covers the period from establishment of the compensation cone to the end of the recharge operation when the fine sand is saturated with water. Therefore, quality interactions between the aquifer and the recharge waters at all the above three stages are possible; while the assumption is that the third stage would have the highest share 
in disrupting the stability of the fine sediments in the aquifer.

\subsubsection{Study of the recharge wells structure}

Bhattacharya (2010) explains injection well, gravity-head recharge well, connector well, recharge pits and shafts methods of subsurface artificial recharge. The greatest number of slides observed during the site visits was around the shafts of the recharge wells, which required a closer study in the context of this research's objectives. Recharge wells are comparatively costlier and require specialized techniques of operation and maintenance to protect the recharge wells from clogging (Arun Yadav et al. 2012). The structure of the recharge wells in the ponds consists of a perforated lining hoop, in which the pores resemble those of the operation wells (creating longitudinal narrow grooves with welding equipment along the pipe's surface) (figure 2). The area surrounding the hoop is filled with sand (gravel pack) up to a radius of $2 \mathrm{~m}$ (figures 4 and 11).

In such cases, due to a reduction in the surface of groundwater inlet and the change in its flow conditions at the borderline between the aquifer, the sand filled areas and the empty spaces along the hoop, the well's efficiency drops considerably. The main reason for this is the ground water colliding with the pipe, deviating and passing through the narrow grooves. This creates a turbulent and non-linear flow around the lining hoop and will ultimately lead to a reduction in the volume of water entering the shaft of the operation well or the opposite, the outflow of water from the recharge well to the aquifer. It should be noted that while this

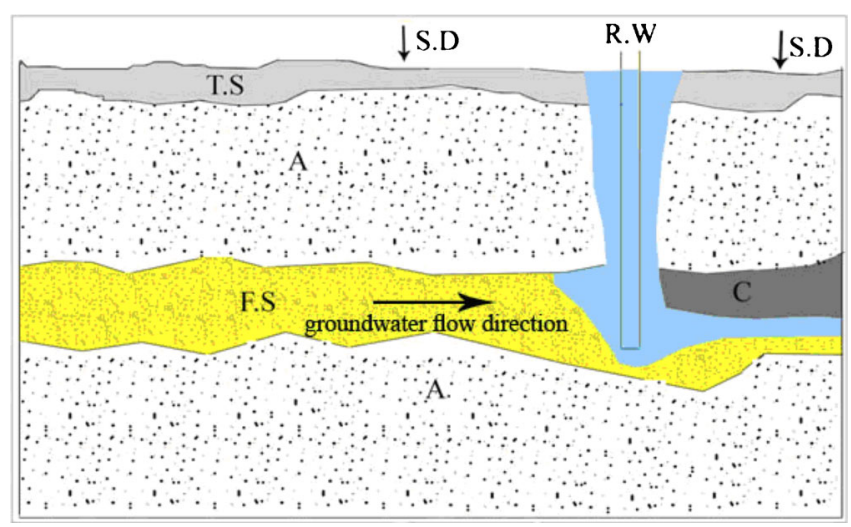

Figure 11. The schematic diagram of cavity, holes formation in depth and land subsidence formation around artificial recharge well in ground surface. S.D is land subsidence, R.W is recharge well, T.S is top soil, A is alluvial, and F.S is fine sand layer which is washed by groundwater flow. $\mathrm{C}$ is cavity that is formed in the direction of groundwater flow. reduction can be compensated by pumping in the operation wells, the solution cannot be applied for the recharge wells. Clogging of wells that are used for artificial recharge is a serious problem (Rostas Voudouris 2011).

It was further observed that after priming of the ponds, water had infiltrated the ground from the gravel pack, gradually washing the sand surrounding the well and gathering greater speed for infiltration (figures 2, 4 and 10). Consequently, the water flow in the cavities around the well shaft resembled more turbulent surface water than the groundwater flowing in a porous environment (the sounds of water flowing underground and the collision of sands and gravels with the well hoops were clearly heard during the site visits). Around the well shaft, there were also cavities of different sizes on the surface and deep in the ground (figures 4 and 10). The main reason for this phenomenon is presumed to be related to the inefficiency of the recharge well's structure. In such wells, the pond water must enter the shaft and then pass calmly from the hoops' grooves though the gravel pack areas to the aquifer. However, as explained previously, this was not the case.

\section{Results}

The results of study area geology, fissures and cracks' structural characteristics measurement, comparison of the chemical analysis of water samples and study of the recharge well structure are as follows:

The geological results show the existence of fine sand and clay layers at different depths of aquifer alluvial such that their displacement is possible with groundwater flow (figure 3). The results of fissure structural characteristics measurement yielded 46 cracks and fissures. The widths of the openings vary between 0.1 and $0.7 \mathrm{~m}$ while the depths of the cracks and fissures vary from 0.1 to $0.35 \mathrm{~m}$ and the fissures length varies between 3 and $200 \mathrm{~m}$ (figures 7 and 8). The comparison of the chemical analysis of water sample results show that the values of electrical conductivity (EC), dry residues (T.D.S) and total hardness (T.h) of water in recharge ponds was much lower than the mentioned parameters in the well samples (figures 9 and 10). Study of the recharge wells structure shows existence of turbulent and nonlinear flow around the well tube narrow grooves (figure 2), pond water had infiltrated the surrounding from well gravel pack, gradually washing (figure 2) the gravel pack and increasing speed of infiltration and groundwater flow. With increasing depth, the groundwater flow washes the fine sand and clay of the aquifer in the direction of its own flow. 


\section{Discussion and conclusion}

\subsection{Discussion}

In the plan for the artificial recharge at South Hamadan Power Plant, the land subsidence at the recharge ponds underlines the consequences of groundwater overdraft and its impact in the Hamadan Plain. These results can be generalized to other areas of similar conditions and applied for design and implementation of artificial recharge plans with the aim of increasing their efficiency and reducing their risks. After the factors of groundwater overdraft and reduction in the volume of aquifer's water, the geologic column of the aquifer alluvial, and the existence of layers of fine sand and clay at different depths, the carbonated and karstic bedrock were identified as among significant and underlying factors for artificial recharge ponds. In addition to the above, the research has noted the significance of fine sand layers in the geological structure of the aquifer, their instability caused by the pumping in wells and in the artificial recharge plan as it relates to the difference in the chemical compositions of the recharge water and the fine sand environment, as well as the negligence of the hydraulic principles of the recharge wells.

\subsection{Conclusion}

The results of the studies reveal the following, which, if considered in similar plains, would prevent the discharge of fine sediments in the aquifer and land subsidence, increase the efficiency of artificial recharge plans, and reduce damages.

The existence of layers of fine particle, especially fine sand in the aquifer alluvial is a major factor in the changes of land structure from the bedrock to the surface of artificial recharge ponds of South Hamadan Power Plant.

As per the data related to the geological structure of the aquifer at the site of the plan, the groundwater overdraft and displacement of fine layers lead to the gradual and general subsidence of the plain and create major and irreversible damages.

The difference in the quality of recharge water and the groundwater aquifer at the site of the plan could be the probable cause of instability in fine layers and their displacement by groundwater.
The negligence of the hydraulic principles of groundwater in the design of recharge wells has led to increase in the speed of groundwater flow around the well's shaft and the displacement of gravel pack and fine layers by this flow.

\section{References}

Arun Yadav, Abhijit Sonje, Priyanka Mathur and Jain D A 2012 A review on artificial groundwater recharge; Int. J. Pharm. Biosci. 3(3) 304-311.

Bhattacharya Amartya Kumar 2010 Artificial groundwater recharge with a special reference to India; IJRRAS 4(2) $214-221$.

Herman Bouwer 1997 Land subsidence and cracking due to groundwater depletion; Groundwater 15(5) 358-364, doi: 10.1111/j.1745-6584.1977.tb03180.x.

Herman Bouwer 2002 Artificial recharge of groundwater hydrogeology and engineering; Hydrogeol. J. 10 121-142, doi: $10.1007 / \mathrm{s} \mathrm{10040-001-0182-4.}$

Huisman L and Olsthoon T N 1982 Artificial groundwater recharges; Pitman Advanced Publishing Program, London, pp. 194-199.

Khorsandi A and Abdali M 2009 Sinkhole formation hazards, case study: Sinkholes hazard in Hamadan Plain and Lar Valley of Iran; Proceeding of the 6th Euregeo Congress, Munich, Germany, pp. 359-362.

Lewis R W and Schrefler B 1978 Fully coupled consolidation model of subsidence of Venice; Water Resour. Res. 14(2) 223-230, doi: 10.1029/WR014i002p00223.

Mathewson C C 1981 Engineering geology, Charles E. Merrill Publ. Co., 410p.

Pewe Troy L 1990 Land subsidence and earth fissure formation caused by groundwater withdrawal in Arizona: A review; pp. 218-233, doi: 10.1130/SPE252-p219.

Poland J F and Davis G H 1969 Land subsidence due to withdrawal of fluids; In: Reviews in engineering geology; Geol. Soc. Am. Boulder 2 187-269.

Rostas Voudouris 2011 Artificial recharge via boreholes using treated wastewater: Possibilities and prospects; Water Journal 3 965-975, doi: 10.3390/w3040964.

Sadati G H and Mohamadi P 2004 The tectonics of Hamadan central plain subsidence holes; Proceeding of the Third Iranian Engineering Geology and Environment Conference; pp. 286-295.

Satish A Bhalerao and Tushar S Kelkar 2013 Artificial recharge of groundwater: A novel technique for replenishment of an aquifer with water from land surface; Int. J. Geol. Earth Environ. Sci. 3 165-183.

Waltman A C 1989 Ground subsidence, Blackie, 202p.

White W B and White E 1995 Thresholds for soil transport and the long stability of sinkholes.

Wilson William L and Beck Barry F 1992 Hydrogeologic factors in affecting new sinkhole development in the Orlando area, Florida; Ground Water 30(6) 918-930, doi: 10.1111/j.1745-6584.1992.tb01575.x. 